\title{
Cooperation of Lean Enterprises - Techniques used for Lean Supply Chain.
}

\author{
Marek Eisler, Remigiusz Horbal and Tomasz Koch \\ Wroclaw University of Technology, \\ adress: ul. Lukasiewicza 5 \\ 50-371 Wroclaw, Poland \\ email: marek.eisler@pwr.wroc.pl, remigiusz.horbal@pwr.wroc.pl, \\ tomasz.koch@pwr.wroc.pl
}

\begin{abstract}
.
The paper presents the problems with integration of the companies within the supply chain. Usually the separate actions are undertaken by the companies to implement lean tools for production systems and external logistics processes. This situation leads to minor results or moving the costs between production and logistics processes instead of reduction. The purpose of the paper is to present the new version of Value Stream Mapping method, focused on synchronised reorganisation of company production system, external logistics processes between the company and its suppliers as well as suppliers' production processes. This paper shows the techniques currently used to support cooperation between enterprises and will demonstrate their incompleteness and how they can be improved.
\end{abstract}

\section{Keywords}

Supply Chain Management, Lean Management

\section{Introduction}

Supply chain management is a discipline that finds enormous interest in last two decades. It becomes now a forefront of business reorganisation. In the previous years supply chain was considered only as material transfer channel. Now, as Lancioni points out, it is and will be the main source of competitiveness [1]. Nowadays, there is no place for fighting only between brands, factories or stores. According to Lambert and Cooper [2] "individual businesses no longer compete as solely autonomous entities, but rather as supply chains." The need of competitiveness is 
now of paramount importance. Therefore, companies need to perform no longer as individuals, they must think about cooperation with other players in supply chain. The source of competitiveness of supply chain was also pointed out by numerous authors ([1], [2], [3]).

Zdzislaw Arlet, managing director of Fiat Auto Poland, claims that suppliers nowadays must be treated as business partners rather than just as suppliers [4]. This way of thinking is a result of policy presented by many OEM manufacturers. They currently need the superior quality as well as on time deliveries according to Frank Guyot, Head of Purchasing Office for Central Europe of PSA Peugeot-Citroën [5]

At the end of last century western manufacturing companies became very interested in the way Japanese produce their goods, especially cars. There was and still exist huge interest in those techniques. Numerous manufacturing companies become aware of the waste that exists on their shop floors and in the offices, especially after publication of The Machine that Changed the World [6] and Lean Thinking by Womack and Jones [8]. Companies have been implementing those techniques and nowadays can demonstrate significant achievements. Authors of the articles believe that the same situation takes place now in Central and Eastern Europe. Many companies try to implement the lean techniques already known well from literature.

In spite of the fact that managers around the globe are aware of problems that exist in their plants and even though they have some achievements with solving those problems, supply chains are not transparent to everybody involved in process of product creation. Many problems can be found not inside the isolated facilities but rather within the relations that occur between cooperating companies. Managers responsible for supply chains need to be equipped with tools that will help them to resolve such kinds of problems. Valuable method in this matter is Extended Value Stream Mapping eVSM proposed by Womack and Jones in 2002 [8]. However eVSM lets to recognize improvement areas within the supply chain, it needs to be complemented by the elements relevant to transportation network reorganization. The main purpose of this paper is to present how the existing method of eVSM might be improved.

\section{Value Stream Mapping and Extended Value Stream Mapping}

In 2002 Jones and Womack [8] proposed a method that allows managers of any supply chain to analyze and find solutions for any value stream that is comprised of manufacturing plants as well distribution centres, warehouses and stores. The method assumes that value stream as well supply chain need to be seen from market demand perspective. The method is based on experiences of Toyota that are described in general as Toyota Production System (TPS) (see [9]). The considered method was called Extended Value Stream Mapping (eVSM) and is an extension to Value Stream Mapping (VSM), a method described by Rother and Shook in 1998 [10]. 


\subsection{Value Stream Mapping}

The VSM method allows managers to perceive their companies from the final customer perspective. VSM helps the practitioners to understand how their plants work at present (the Current State Map) and to plan the improvements in approaching 9-12 months (the Future State Map). The VSM analysis is usually performed for plant level from raw materials to finished goods. It allows identifying the status of manufacturing system in any plant and to plan improvements with use of lean techniques such as level pull system, one piece flow cells, SMED, TPM and others. Usually the VSM analysis takes a few days. The result is a Future State Map drawn by managers and engineers depicting precisely what tools should be used in what areas of the plant.

\subsection{Extended Value Stream Map (eVSM)}

VSM method is not limited only to a single manufacturing plant. Jones and Womack [8], Rother and Shook [10] suggest starting VSM process on a plant level and then extend the analysis for supply chain level. Such analysis should encompass in the beginning only selected, manageable part of the whole supply chain. It is obvious that if eVSM would be used to analyze OEM and all of its cooperating companies, the map would be very complex and therefore difficult for analysis. That is why eVSM teams usually start to draw maps only for limited fragment of the supply chain. After recognizing problems and implementing the solutions for the chosen fragment the team might repeat eVSM analysis for other suppliers [8,9].

The eVSM method functions in following way: the mapping team members draw a Current State Map, including both material and information flows, for selected branch of supply chain, then using the lean tools and methods they design the Future State Map. The output of this process, beside a Future State Map, is an implementation plan including the set of projects that must be put in action [8].

\subsection{Limitations of Extended Value Stream Mapping}

The eVSM method is a very supportive tool to begin supply chain improvement by implementation of such techniques as pull system, just-in-time deliveries and others. The main problem that may occur is lack of willingness of managers of cooperating companies to share the knowledge about their plants and warehouses. Another problem that may occur is a fear of managers of particular plants that they will not benefit from the whole improvement process $[1,10]$. Witkowski in "Logistics of Japanese firms"[10] claims that Western companies (Europe, USA) are not willing to cooperate with their business partners to find better and cheaper solutions for their problems. They usually focus on unit price and quality level accepted by costumers. It is hardly to find fair rules that would allow benefiting both supplier and costumer from the outputs of improvements made together within supply chain. It is observed that common effort of suppliers and consumers is mostly made to improve quality, but the efforts to reduce the waste are rather limited to the separated actions within the plants.

Another problem that may occur while using eVSM method is existence of other costumers and suppliers for individual plants that are not involved in an analyzed 
branch of a supply chain. The main issue of the eVSM method is to reduce inventories that are waste from costumer's point of view. When users of eVSM try to reduce excessive inventories it is often related to increased frequency of deliveries. Higher frequency of deliveries results in smaller transportation batches, however it might lead to higher transportation cost. This will be the case if the delivery frequency is increased without redesigning of transportation routes $[12,13]$. Jones and Womack suggest taking advantages of optimizing transportation with "milk nuns". As Baudin claims "a supplier milk run is a scheduled pickup of parts from multiple suppliers in matching quantities (..)" $[12$, p.131]. Milk run idea is depicted in the fig 1 .

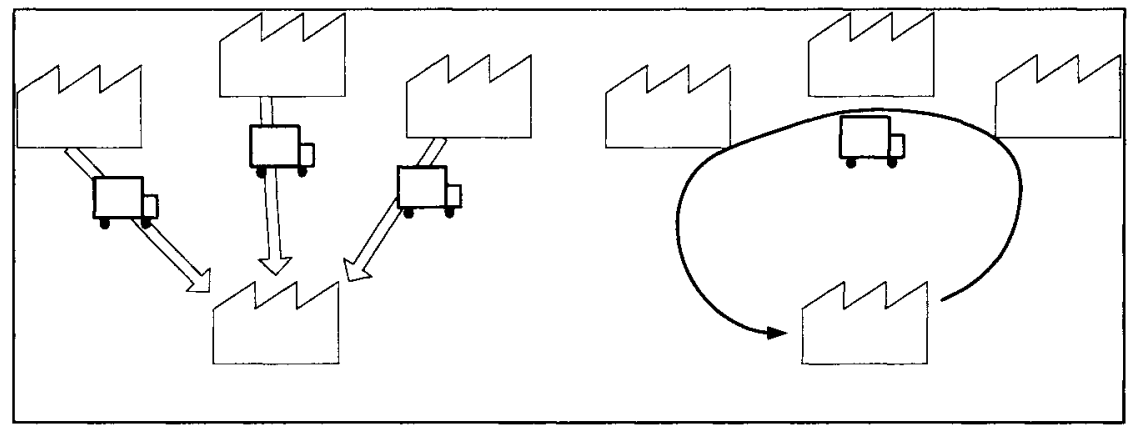

Fig 1. The concept of milk run versus direct shipments.

eVSM method does not support transportation route analysis and is focused only on the selected value stream. These both aspects are crucial to design milk run deliveries. The next section of this paper presents how to complement eVSM method with transportation route analysis.

\section{Incorporation of transportation route design within Extended Value Stream Mapping.}

In the proposed approach the new elements were added to eVSM to put more attention to visualization of transportation links. These elements allow designing more precisely the milk run deliveries in order to lower the inventory levels. There are several approaches of milk run design. One of them is to add few suppliers that provide small amount of parts to one or two suppliers providing large amount of parts for the costumer. This approach leads to better vehicle utilization as well as to higher frequency of deliveries. To design well operating milk runs, the following issues must be taken into consideration:

- Cost of vehicles being currently in use and its utilization level to calculate existing transportation cost.

- Number of suppliers located in the proximity and delivering to the one, common customer to design potential milk-run route.

- Distances among suppliers and customer to calculate the transportation costs for designed milk-run route. 
To visualize those issues on the map the three new map elements are proposed:

\section{The truck cost and utilization}

This entity is shown in the fig. 3 and represents the information about the transportation cost of the vehicles currently in use. It provides as well information about actual utilization level of vehicle transportation space. For example the symbol in the fig. 2 shows utilization at the level of $25 \%$; the transportation costs is $0,75 €$ per $1 \mathrm{~km}$. These kind of data let to have a closer look for actually incurred costs of transportation. Including this data on the map lets to estimate roughly if designing milk runs will be economically justified.

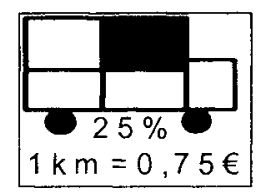

Fig. 2. Proposed symbol of transportation vehicle being currently in use.

\section{The milk run area}

The second proposed element allows gathering data related to geographical location of the suppliers considered to be served by designed milk run transportation process. The symbol that is presented in the fig 3 summarizes data about number of existing suppliers that deliver to the customer as well as the size of the area. For example in fig 3 there are 3 cooperating companies that should be taken into consideration as points for a milk run. All these companies are located in the radius of $50 \mathrm{~km}$ from the centre of the area.

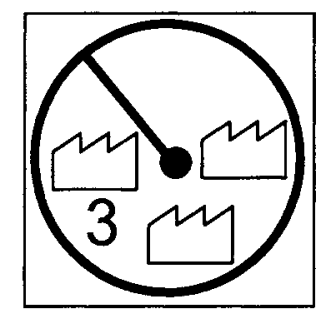

Fig. 3. Proposed symbol that would summarize data about number of existing plants and warehouses that supply particular customer and the distance between them.

\section{The milk run route}

For the Future State Map the milk run route symbol is proposed (see in fig.5). During designing of the future state map the chosen milk run areas will be transformed into milk run routes. The proposed milk run route symbol will let to estimate the transportation costs for the designed milk run. It provides data about number of points in a particular milk run loop (for example in the fig 5 there are 6 points in the loop) and about overall length of the loop (150 km in the fig.4). 


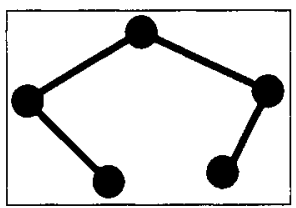

Fig. 4. Proposed symbol for designed milk run route.

\section{Example of usage of proposed method.}

eVSM method was used for a case study conducted with a Polish producer of industrial valves. To simplify the analysis only two cooperating companies were taken into consideration:

- the manufacturfer of industrial valves - 'OEM',

- one of the suppliers of OEM- 'Supplier A'.

Both companies were analysed and the Current State Map was drawn (see in fig 5).

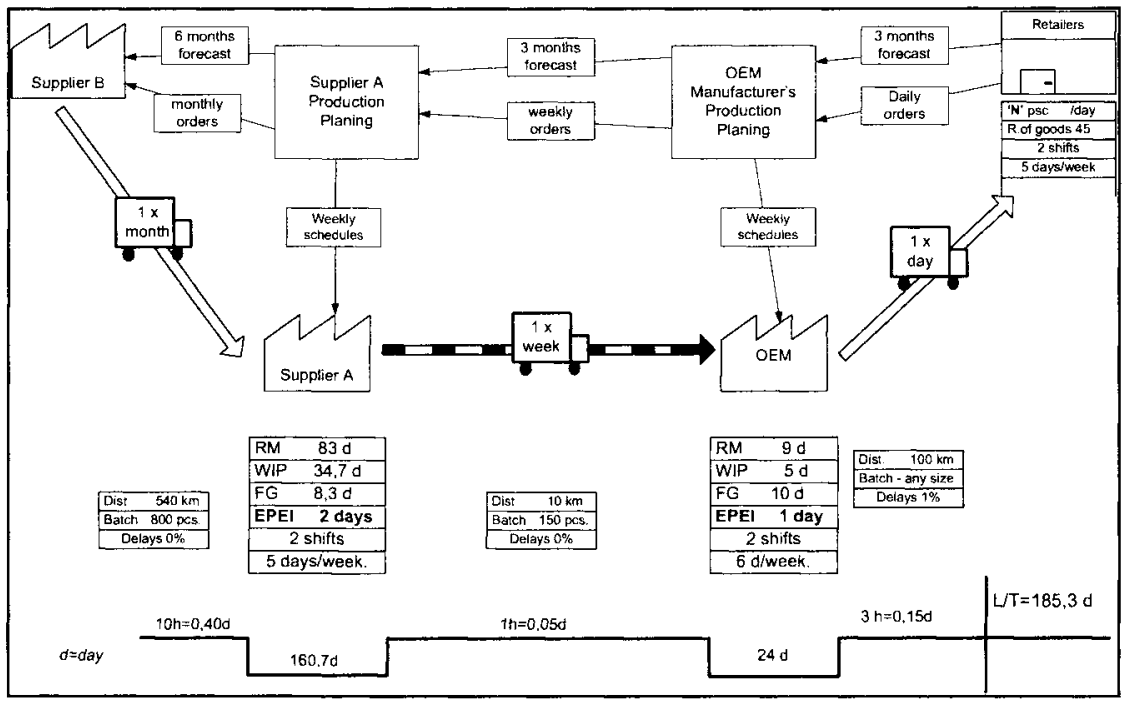

Fig. 5. The Extended Value Stream Map for analyzed case (Current State).

During the analysis it was decided that material flow from supplier to the customer will be reorganised and based in future on replenishment pull system, often called supermarket pull system or kanban system. Basing on the collected data and guidelines proposed by Harris and Wilson [14] the target inventory levels for both cooperating companies were calculated. Authors inferred that the levels of raw material (RM) inventory in customer company (OEM) mostly depends on frequency of deliveries from the supplier (Supplier A). This conclusion comes from analyzing of equations proposed by Harris and Wilson [14] to calculate target inventory level for supermarket pull system. The maximum inventory consists of three parts:

- cycle stock,

- buffer stock, 
- safety stock.

These three types of stocks might be calculated as follows:

- cycle stock $=($ average daily consumption [pcs.]) $x$ (replenishment time [days])

- buffer inventory $=$ (maximum daily consumption [pcs.] - average daily consumption [pcs.]) $\mathrm{x}$ (replenishment time [days])

- safety stock $=($ cycle stock + buffer stock $) \times($ safety factor $[\%])$

As pointed out above, inventory level strongly depends on frequency of deliveries. Practitioners conscious about this issue may be confused while using eVSM method because increasing deliveries frequency comes together with significant increase of transportation costs. To keep those costs constant implementation of milk run is essential, but with eVSM method there is not enough data to consider implementation of such solution. Therefore the second Current State Map was prepared (see in fig 6). For the second Current Stat Map proposed new elements were used. With these elements the additional data necessary to design new milk run routes are available on the map.

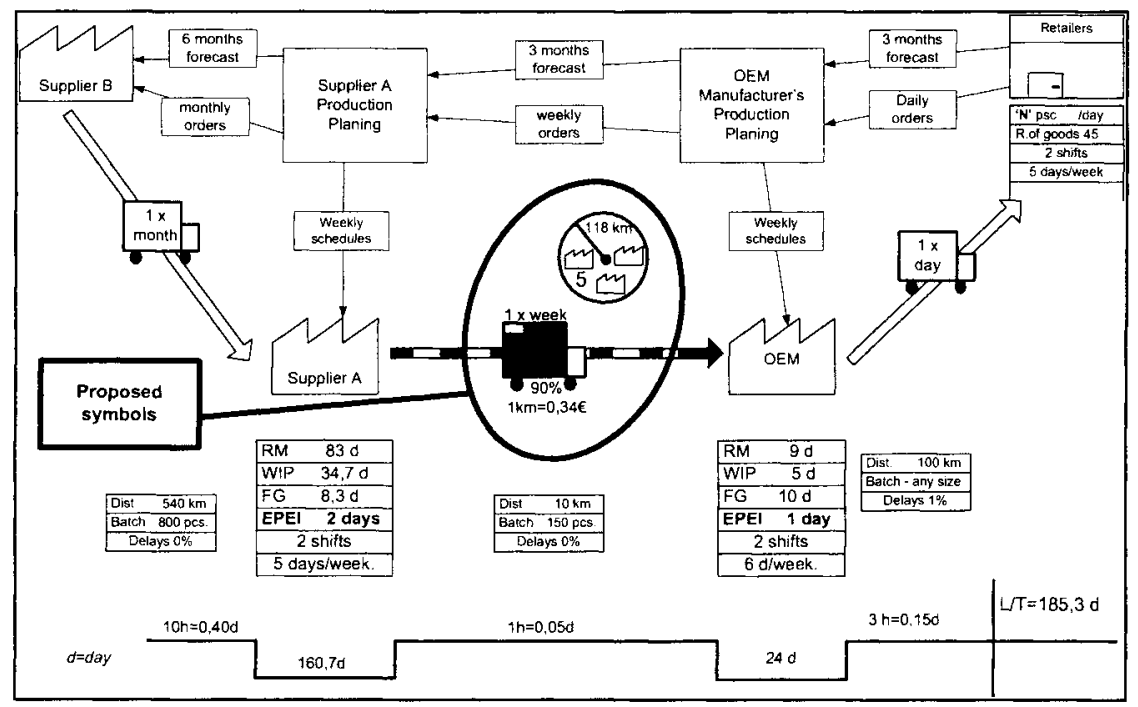

Fig. 6. The Extended Value Stream Map for analyzed case (Current State) with proposed symbols.

The Current State Map complemented with new elements led to the decision about designing daily milk-run encompassing Supplier 1 and 4 other suppliers. The length of the route is $300 \mathrm{~km}$. Implementing it will let to increase the delivery frequency from Supplier A to OEM from one week to one day, which in turn will lead to raw material stock reduction (on OEM's side) almost by $80 \%$.

\section{Conclusion.}

Complementing the eVSM method with transportation route data proposed in this paper would allow managers to make easily decisions about designing milk run 
routes and make right strategic decisions quicker, without time consuming investigation of all the possibilities. Thanks to such solutions supply chain will become more agile and more competitive while inventory levels will be decreased with higher frequency of deliveries. The described case-study proved that the milk run areas identified during current state analysis may be transformed in the real milk run routes later in the phase of designing new solutions for the supply chain.

\section{References.}

1. Lacioni, R. A., New Developments in Supply Chain Management for the Millennium, Industrial Marketing Management, 29, 1-6, 2000.

2. Lambert D., Cooper M., Issues in Supply Chain Management, Industrial Marketing Management 29, 65-83, 1999.

3. Porter M., Competitive advantage: Creating and sustaining superior performance, New York, NY: Free press.

4. Arlet Z., Our way to success, Conference proceedings of $3^{\text {rd }}$ Annual Conference of Automotive Industry in Poland, Poznan, May 2007.

5. Statements at the Autoevent May 23th-25th, 2007, Poznan, Poland

6. J.P. Womack, D.T. Jones, The Machine That Changed The World. The Story of Lean Production, Harperperennial, New York, November 1991.

7. J.P. Womack, D.T. Jones, Lean Thinking: Banish Waste and Create Wealth in Your Corporation, Simon \& Shuster, New York 1996.

8. J.P. Womack, D.T. Jones, Seeing the Whole: Mapping the Extended Value Stream, Lean Enterprise Institute, March 2002.

9. Ohno T., Toyota Production System: Beyond Large-Scale Production, Productivity Press, New York, 1988.

10. Rother M., Shook J., Learning to see., The Lean Enterprise Institute, 1998.

11. Witkowski J., Logistyka firm japońskich, Wydawnictwo Akademii Ekonomicznej im. Oskara Langego we Wrocławiu, Wydanie 2, Wroclaw 1999.

12. Budin M., Lean Logistics. The nuts and bolts of delivering materials and goods.

13. Cooper R., Slagmulder R., Supply Chain Development for the Lean Enterprise: Interorganizational Cost Management., Productivity Press, June 1999.

14. Harris R., Harris C., Wilson E., Making Materials Flow: A Lean MaterialHandling Guide for Operations, Production-Control, and Engineering Professionals., The Lean Enterprise Institute, September 2003. 